I-Pop: International Journal of Indonesian Popular Culture and Communication

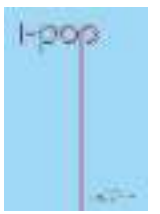

Vol. I (I) pp. 13-20, (2020) DOI: I0.36782/i-pop.vlil.27

\section{Spornosexual Capital: the Economic Crisis of Indonesian Urban Masculinity}

\author{
Dian Arymami ${ }^{*}$
}

\begin{abstract}
The emergence of new digitally mediated body practices among the young, middle class, and male is evidence of a recent shift in the modern power hierarchy. An increasing number of men go to the gym and share pictures of their bodies that had begun globally around 2008 . This coincides with the intensification of neoliberalism that cannot be separated from the massive development of digital communication. This phenomenon is also evident in developing in Indonesia, giving birth to new forms of male body mediation. This research explores how spornosexual men mediate their bodies publicly in relation to the shift in digital neoliberal culture. Using the reception analysis through interviews, this study takes 5 spornosexual people in deciphering neoliberal interconnection through the use of the body as capital. The results show spornoseksual has become a new capital amidst our daily lives today.
\end{abstract}

Keywords

Neoliberal, digital culture, body, male, metrosexual

To cite this article ( $7^{\text {th }}$ APA style):

Arymami, D. (2020). Spornosexual Capital: the Economic Crisis of Indonesian Urban Masculinity. I-Pop: International Journal of Indonesian Popular Culture and Communication I(I), 13-20. http://doi.org/I0.36782/ipop.vlil.27

\section{INTRODUCTION}

Since 2008, the images of young British men with an athletic body is rose in the social media (Hakin, 2016). Uploaded muscular male bodies with the impression of obsession with sports and appearance of their bodies soon spread in various countries, including Indonesia. The expansion of these pro-health athletic body images is termed spornosexual, a term and further concept of metrosexual development.

'Department of Communication (DIKOM), Universitas Gadjah Mada, Yogyakarta, Indonesia

"Corresponding author: d.arymami@gmail.com
Spornosexual uploads are became a trend. The reality of uploading spornosexual photos on Instagram can be observed from the link between fitness and selfie that has been named the word of the year by the Oxford English Dictionary in 2013 and Healthiest and has become a popular hashtag word on Instagram social networks (Hakim, 2016, p. 3). Based on data from top-hashtags.com, it was found that the hashtags related to the term spornosexual were in the Top 100 Hashtags, such as \#fitness (238 million) ranked 30th, \#gym (II8.I million) in position 66 and \#workout (98.62 million) are in position 87. Narcissistic behaviour of spornosexual men is also supported by the number of \#selfies (329.4 M) 
which is ranked 14th and out of 329.4 million selfie uploads \#gymselfie ranks 9th with the number of uploads amounting to I,927 million.

None the less, in Indonesia, spornosexual became an expression of new masculinity within this digital era. Various male artists rose to the expression including Andrew White (@) andrew.white._), Rory Asyari (@roryasyari), Marcelino Lefrandt (@marcelinolefrandt), Randy Pangalila (@randpunk) and many more.

Experts have seen this phenomenon in correlation to healthy living trends and a matchmaking events. This phenomenon is also seen as similar to when women use sexy clothing to accentuate bodily curves (Anjani, 20I5). Another point of view describes the phenomenon of body worshipers as a symptom in urban areas that leads to narcissistic culture (Windarti, 2015). However, as Hakim (2016) explained, the widespread practice of uploading these images can be seen as an inevitable shift in capital from the assumption of an economic crisis. The decline in economic power, historically shows the shift of capacity to earn a living through bodily labor. The presence of bodily work demonstrates the practice of the structure of feeling (William, 2008) which can be seen as the fruit of neoliberalism.

An argument can be built that the outbreak of the mediated male body image in Indonesia is part of a shift in earning capacity and an indication of the financial crisis; in which can be related to the ongoing work of the body represented through social media.

The representation of men's bodies in the middle of social media globally is understood as a spornosexual designation. Spornosexuals are a group of men who think of themselves as a whole and sacrifice a lot of things to make their bodies look good despite having to do cosmetic surgery. Hakim (2016) explained how being spornosexual men requires an effort to upload photos / images and compare their physical appearance on social media. They chose their images to be used as objects of others, in this case uploading photos / videos of shirtless on social media in the form of Instagram feeds, selfies and spornosexuals (Hoojidonk, 2017, p. 17).

Neoliberal culture has been widely used to help understand various aspects of cultural practices that have emerged lately. The main principle of neoliberal ideology is that redistributive social democratic states are basically tyranny, inhibiting the capacity of individuals for autonomous, competitive, hardworking entrepreneurship (Hall, 20I I; Gilbert, 2013). Therefore, the ideal subject of neoliberal ideology is the individual autonomy related to each other in a competitive, market-based manner in all areas of social life.

Lauren Berlant (20II) in her book Cruel Optimism explains neoliberal interconnection by describing the logical results of existence in a society where fantasies about what constitutes a good life have become so spectacular (eg. the culture of the consumers of the global rich), but the way to achieve them has diminished in a way that is radical. The community is optimistic about things that are not possible - because of its cruelty - and as a result the community is always in a state of being always awake.

Berlant did see the manifestation in Cruel Optimism, but only in relation to ways that were classified and accelerated so that the so-called 'global obesity epidemic' had manifested itself in capitalist culture since the 1970s. Berlant argues that over eating low-cost processed food industries offers a 'reprieve' from the pressures of everyday life in a neoliberal economy where humans are expected to work more at lower wages and with less labor rights - especially for people colour, youth, workers and subproletariats (Berlant, 20 I l:95-20).

Similar problems can be seen in relation to social groups applying various types of bodily practices in response to the same historical circumstances. Efforts to reach the body by exercising can be seen as a sign of losing power. As discussed above, under the modern regime of power, it is a sign of subordination if you 
belong to a group whose main way of creating value in culture is through the body.

\section{METHOD}

This research is a qualitative study using reception analysis in which audiences are seen as part of interpretative communities who are always active in perceiving messages and producing meaning, not just being passive individuals who simply accept the meanings produced by the mass media. Reception analysis is an in-depth study of the actual process through which discourse in the media is assimilated into public discourse and cultural practices. According to Denis McQuail (1997), reception analysis emphasizes the use of media as a reflection of the socio-cultural context and as a process of giving meaning to an experience and cultural production. This study focus through in-depth interviews of 5 men chosen from snowball between gym freak group spornosexual men.

\section{FINDINGS AND DISCUSSION}

\section{Body Capital in the Digital Neo-Liberal Culture}

Raymond Williams's concept of 'feeling structure' (2008) offers a useful frame for the phenomenon. According to Williams, 'structure of feeling' is the way it feels to live during a certain historical moment and can be traced through an analysis of popular culture from certain social formations. Various methods have been used to analyse popular culture to map the structure of feelings and affective states more generally such as the textual analysis (Berlant, 20II) conjectural analysis (Grossberg, 2010) and auto-ethnography (Kyrola, 20l4).

The interviews of the participant are semi-structured and focus on how they achieve their exercise body and how they share their images on social media, whilst also exploring the motives of involvement in these practices.

The interviewees were men who worked as fitness professionals or who did the practice in their free time. All interviewees can be identified as upper middle class with ages between $20-35$ years. One of those interviewed claimed to be homosexual and the rest was heterosexual. The findings show no difference in preference for sexuality interest in this study. Interviews last from one to three hours, and the results of the data are classified as the main discourse that often arises.

The interviewees' description of their involvement with this new form of bodily work is supported by the logic of neoliberalism in two ways. One is how hard the participants need to work to achieve their goals, but has a little meaningful return. This is similar to Berlant's terms, striving for a broad transformation that was not possible to attain the capital; specifically in the various forms of capital that were developed by Pierre Bourdieu (1986). Secondly, the aspects of ideology where self-fashioning in accordance with the ideals of beauty embodied in the visual culture of consumer capitalism.

Various studies have tended to approach the phenomenon in the notion of selfrepresentation in digital culture (Senft and Baym, 20I5; Tiidenberg and Gomez-Cruz, 2015; Kurniasari \& Rachmah, 2017; Nørlev, 2016.). As Hakim (2016) mentions that this practice cannot be reduced to the matter of representation per se, because it is inseparable to the competencies and knowledge of exercise, digital photography, the usage of social networking sites where the participant acts as a prosumer.

\section{Working the Mediated Body}

The participants that had described the body work that they put in both producing muscular bodies and sharing images on social media platforms are both professionals and nonprofessionals. Dedi, as professional fitness attends the gym in a daily basis. He spends to the least of two hours to four hours exercising and building his body. $\mathrm{He}$ is also keen in ensuring the nutrition from the meals he took daily, with precise calculated type and amount to build the muscular body he intended. Besides being a professional, he's also undergoing a degree in sports which may contribute to the work he 
spend in the gym. There's also a nonprofessional, Jon whom described that the ideal body as 'being toned - muscular arms, muscular shoulders, thin waist, V-shaped, nice legs, rounded bottom'. This picture becomes important in regard to the visual images for consumer brands of neoliberal capital accumulation. As a non-professional, Jon works to shape his body more religiously, spending mornings and evenings at the gym.

There's also, Willy is a respondent who can be seen as a conscious participant in body work images as he tend to be precise to how he produce his body image. Choosing backgrounds, and certain specific moments was felt to be more convincible in creating the body build masculinity. This is interesting as the logic informs 'brand self' practices on social media platforms as part of neo-liberal ideology (Hearn, 2008; Banet-Weiser, 20I2).

He would pose to have someone take his picture and consciously chooses and produces images in a way that will maximize his sexy look. The subjectivity of the word 'sexy' is described by the little amount of fat and the more muscular his body tone is. Various technics are brought at play; from cropping to colouring the image before uploading to the public eye through his social media account. This shows awareness of the instructional medium itself as part of his representation. None the less, he acclaimed that there was a desire to gain the amount of likes on his account and positive comments on his posts that feed well to his motivation.

The spornosexual capital designed to be produced by bodily labour is explained by respondents in which does indicate as Hakim (20II) explains a form of spornosexual capital that combines erotic capital with social capital. A desire to look sexy, as Willy described would be an example of how the erotic capital comes to play.

Erotic capital in this sense cannot be separated from social capital, as networking sites facilitates various social capital through likes and comments. As Harvey et.al. (2013) describes social capital can be measured by the number of likes, tags, shares, and comments that images receive. All the participants have similar opinions about why they have started the practice of body work out, which highlights their notion on the importance of look or appearance.

Other than that, the opinion on health is also mentioned later on in connection to the practice of body building. As Jon explained he was driven by building appearance and "it makes us a healthier person". Health was also mention by Dedi, after experiencing the practice of body work which was motivated at first by the the need to enhance his look through his body tone; "Temen-temen ama cewek-cewek pada suka. Orang kan menilai kita dari tampilan ya" (Friends and girls like the look. Isn't from appearance people judge us).

Both participants above acknowledge and play with erotic capital that is apparent to the intertwining social capital, the likes and the social interaction they acquire from the body works. Both of these participants also gain value in health which plays an addition to their motivation to continue practicing body works. Never the less of this additional value, not much of the posts they upload on the social networking sites, namely Instagram having the tendency of healthy living in comparison to the erotic capital.

All participants have mentioned the importance of peer responses to the images they produce and circulate through their social media, but there is an important difference significant in highlighting between the fitness professionals and non-professionals.

In regard to Bourdieu's notion of capital, the most important element is the exchange value one has outside the field in which one accumulates. Hence the ability to convert this spornosexual capital represented in the social media sites to an economic capital is significant. Although it is apparent that the conversion between capitals is not always economic. For 
professionals there are notion in the ability to convert spornosexual capital into economic capital even though it is limited. As Dedi explains that with his sport degree and fitness group interactions or that of a more conventional form of cultural and social capital plays a greater role in advancing his career than the number of followers; "gak masalah kalo ditutup.. kan dengan gelar dan media lain mereka sudah kenal juga ama $a k u$ " (it couldn't matter even if they close the account because with my degree and other media people would already know me).

Conversion of spornosexual capital to economic capital can logically relate as it is a common practice that in the fitness industry, likes, followers, tags, comments, etc. is one of the reasons clients decide to use their services. Hence the uses of the personal networking sites for professionals are an addition to enhancing their economic capital.

In the other groups of non-professionals, conversion of capital is very much intertwined with the working ideology of capitalism. Nonprofessionals mainly talk about how affective they are for receiving (or not receiving) likes, comments, tags etc. in relation to gaining the infinite and a notion of pseudo goals driven by images, dreams and idea in the effectiveness of body work practice.

Willy, a non-professional for example articulated how spornosexual has become turned into simply an obsession that has nothing to do with social or economic capital. It has become a constant state of pursuit and continues to erode reality. He explains as this practice is parallel to obsession and anxiety, a constant judgement of his own body; "ini kurang besar gak ya? Ini kebanyakan lemak gak ya? Ini perlu diapain ya? Rasanya ga habis-habis dan kadang mikir buat apa?" (Is this too big? is this too much fat? what else do I do? It's never ending, and whatever for?).

The endless practice of body works that all participants recognize spread into two extreme opinions; that of the negative notion, just as Willy had exclaim and criticize his own practice and that of the positive notions generally found through the professionals. Dedi as an example describes how the lack of the body image always motivates to work on endless perfection.

It is interesting to put forward that the possibility of economic capital conversion drives the positive notion, in which is not separated to how the idea and works of the liberal capitalism. But this also does not exclude how the idea and works of the liberal capitalism within nonprofessionals that may not have an apparent conversion to the economic capital. The competence of driving the social practice and pursuing the dream image is also within the works of capitalism even though one may hardly understand the reason or the limit of their pursuit.

This can be drawn as a conclusion to where the practice of body work for both professionals and non-professionals are equally endless work in which they produce increasingly depleting capital with limited exchange rates.

The described production and consumption of body work above shows as what Berlant (20II) describe as 'cruel optimism'. The term 'cruel optimism' suggests, inhabiting the critical space opened by neoliberal austerity is a contradictory experience constructed from a complex mix of positive and negative influences. For some and most professionals that share a more positive notion on the practice brings out a contradiction of the capital conversion; working hard for body works with very little in economic return. Whilst for others the contradiction shows on how an active criticism of the practice is acknowledge but has very little to the influence of their behaviour.

These notion of contradiction can be found in their expression of the experience. For example Dedi exclaimed that it made him feel determined and proud as the public can see the results of his 'hard' work. Or how Jon has explained the joyous experience of acknowledging he can amount a heavier weight 
and how this is all shared through documentation in his social media account; "ada yang menyenangkan saat melihat photo di insta.. termasuk komentar orang-orang yang positif' (theres an excitement to look at the photos in instagram.. also the positive comments from the public).

The participants choices of words to explain the joyous experience in body shaping and work practice also shows how the joyous notion; 'pride, excitement, happiness' are attained in these cultural practices through hard work without a definite value of stability.

In the opposite notion, in where the contradiction shows within the acknowledgement and criticism of the practice is not parallel to the behaviour brings out the element of obsession and addiction that are carried out in capitalism. As mentioned above, Willy questioned what the practice accumulates to besides an indescribable obsession. There was an apparent confusions or even said to be contradictive within his own criticism; "maksudku.. kenapa photo diri, ngapain coba diunggah? Cuma mau dianggap luar biasa gitu.. gak tahu deh.. agak gak sehat, semua nge-gym, photo, unggah, dapat komentar.. buat apa..” (I mean ... why do we bother sharing our photo it? just to be considered extraordinary? I do not know.. It's a bit unhealthy, everyone goes to the gym, photos, comments.. What for?).

The engaging practice of bodywork that are in prior described as a healthy practice for the physical body is in contradiction to the further expression of unhealthy behaviour. These contradictions shows complexities that are warped in the neoliberal culture. Else, the reoccurring phrasing of obsessions and addictions on the issue of spornosexual in social media, saturates the characteristics of the neoliberal cultural context.

Besides the process of body work and producing of body image in the social media, these obsessions are also described in the process of consuming the body image through social media. Markus as an example narrates how he unconsciously spend time scrolling through spornosexual images in Instagram and acknowledge how consuming the image has become a certain addiction.

In the same notion of contradiction, Markus explain how this unconscious addictive behaviour, in which may be categorise as a negative behaviour is forgivable because in the same time offers a motivation to work on the body. These responses have highlighted the concept of cruel optimism in Brelant's writings that warps within the neoliberal culture. The act in pursuing these images have given satisfaction yet spurs confusion in the purpose of the pursuit itself. Such notion can be seen as well through the explanation of the rhizome characteristic brought by the human desire in the works of Deleuze and Guattari (1980); as an alternative to understand the contradictions apparent in a saturated capitalistic society.

Nonetheless, as different experience and subjectivity explained through the practice of spornosexual mediation in social media these contradictions has not changed the endless work of body the participants put into daily. What can be abstracted through these descriptions on cultural practice of the body is the possibility of how the neoliberal cultural pratice shapes the human body in society; that of which is none the less how neoliberalism becomes the master hegemony.

\section{CONCLUSION}

The emergence of sharing images of toned body men on social media platforms grew within 2008. Globally, there has been a range of social and cultural indicators that shows how more young men are involved in shaping muscular bodies. Arguably, the most significant indicator comes from data produced by the Active People survey (2014) which measures weekly sports participation in the UK and found a significant year-on-year increase in the number of men aged 16-25 years attending a gym. The number increased significantly between the years 2006 to 2013 , reaching the growth of $21 \%$. Market 
Research Company Nielsen also found that sales of sports nutrition products increased by $40 \%$ and has become the second largest growth in sales of any product sold in supermarkets in the year (Smithers, 20I4). These emergence of body image shared through the social media has become a phenomenon.

The phenomenon was also found in Indonesia. An escalating number of male images with muscular bodies fill the social media, namely Instagram as one of the most popular social media sites in the country. These images can be seen as the embodiment of men that came to be known as spornosexual. It can also be understood as part of the practice that intersects with the structure of feeling created by the context of neo-liberalism. Historically the shifts in conventional work towards bodily work is caused by an economic downturn.

Through the semi-structured interviews between fitness professionals and nonprofessional men in Indonesia, Berlant's concept of 'cruel optimism' is apparent with the paradoxical condition resulting from neoliberalism. The conversion of spornosexual capital were found filled with pseudo pursuits that paralyzes the participants into contradictive conditions.

The findings of this research offers a further insight of the ongoing neoliberal culture, where territorialisation of the desires and subjective opinions becomes a part of the neoliberal hegemony flow. The body of the neoliberal culture is none the less shaped by this hegemony, even though the awaken eyes of the cruel optimism. Thus, the practice of spornosexual capital in the social media is a piece of the rhizomic self that had flourish from the neoliberal culture that takes place in our daily lives.

\section{References}

Active People Survey (20/4). Who Plays Sport. Sport

England.

http://www.sportengland.org/research/whoplays-sport/

Anjani, R. (20I5, February 16). Maraknya Tren Gaya
Hidup Sehat Bisa Mendorong Pria Jadi Spornoseksual [The rising Trend of healthy lifestyle Encourage men to be spornosexual]. Detik.https://wolipop.detik.com/read/2015/02/06 / 150234/2825885/ I /37/maraknya-tren-gayahidup-sehat-bisa-mendorong-pria-jadispornoseksual.

Banet-Weiser, S. (2012). Authentic: The Politics of Ambivalence in a Brand Culture. New York University Press.

Berlant, L. (20I I). Cruel Optimism. Duke University Press.

Bourdieu, P. (1986). The forms of capital. In J. Richardson (Ed.). Handbook of Theory and Research for the Sociology of Education (pp. 24I258). Greenwood.

Deleuze, G. and Guattari, F. (1980). A Thousand Plateaus: Capitalism and Schizophrenia. Translated by Brian Massumi. Reprint Edition, 2004 [1987]. Continuum

Gilbert, J. (20/3). What kind of thing is 'Neoliberalism'? New Formations 80/8I, 7-22.

Grossberg, L. (2010). Cultural Studies in the Future Tense. Duke University Press.

Hakim, C. (20I I). Erotic capital: the power of attraction in the boardroom and the bedroom. Basic Books.

Hakim, J. (2016). The 'Spornosexual': The Affective Contradictions of Male Body-Work in Neoliberal Digital Culture. Journal of Gender Studies Vol 27, 20I8, 23I-24I.

Hall, S. (20I I). The Neo-Liberal Revolution. Cultural Studies, 25(6), 705-728.

Harvey, L., Ringrose, J., \& Gill, R. (2013). Swagger, Ratings and Masculinity: Theorising the Circulation of Social and Cultural Value in Teenage Boys' Digital Peer Networks. Sociological Research Online, 18(4), 57-67. https://doi.org//0.5153/sro.3153

Hoojidonk, R. V. (2017, n. d.). The Ideal Man: Past, Present, Future. Richardvanhooijdonk.com. https://www.richardvanhooijdonk.com/en/ebook s/man-future-ideal-man/

Kurniasari, L. and Rachmah, E. N. (2017). Relasi Narsisme dan Konsep Diri pada Pengguna Instagram [Interconnection of Narcisism and Self Concept among Instagram Users]. Prosiding SEMNAS Penguatan Individu di Era Revolusi Informasi. Surakarta

Kyrola, K. (2014). The Weight of Images: Affect, Body Image and Fat in the Media. Ashgate.

McQuail, D. (1997). Audience Analysis. SAGE 
Publications

Nørlev, B. H. (2016). The Self-Promotion of Spornosexual Men on Instagram. Bachelor Thesis of Arhus University.

Senft, T. and Baym, N. (20I5). What Does the Selfie Say? Investigating a Global Phenomenon. International Journal of Communication, 9(19), I5881606.

Smithers, R. (20|4). E-cigarettes and sports nutrition products lead grocery sales boost. The Guardian. http://www.theguardian.com/business/20l4/dec/ 30/e-cigarettes-sportsnutrition-supermarketssales-rise-uk

Tiidenberg, K and Gomez Cruz, E (20I5). Selfies, image and the re-making of the body. Body and Society, 2I(4), 77-102. https://doi.org/ I0.I I77//357034XI5592465

Williams, R. (2008). Towards a Recognizable Theory of Culture. In D. Walton (Ed.), Introducing Cultural Studies: Learning through Practice (Pp.II0-136). Sage

Windarti (2015, August 13). Tren Pamer Tubuh Spornoseksual dan Seks Terselubung [Trends to show off the body of Spornosexuals and Covert Sex]. CNN Indonesia. https://www.cnnindonesia.com/gayahidup/20150 8I3 I85248-277-72040/tren-pamer-tubuhspornoseksual-dan-seks-terselubung. I 3August 2015

\section{Notes on Authors}

Dian Arymami is a lecturer, and researcher from the Department of Communication Science, Universitas Gadjah Mada Yogyakarta Indonesia. She pursued her PhD in Media and Cultural Studies from Universitas Gadjah Mada. Her main interests include communication and media studies, human interaction, sociocultural psychology, and gender studies. E-mail: d.arymami@gmail.com. 